\title{
Don't forget to look down - collaborative approaches to
}

\section{predator conservation}

Steve Redpath ${ }^{1,2,}{ }^{*}$, John D.C. Linnell ${ }^{3}$, Marco Festa-Bianchet ${ }^{4}$, Luigi

Boitani $^{5}$, Nils Bunnefeld ${ }^{6}$, Amy Dickman ${ }^{7}$, Ralph.J. Gutiérrez ${ }^{8}$, R. Justin

Irvine $^{19}$, Maria Johansson ${ }^{10}$, Aleksandra Maji ${ }^{11}$, Barry J. McMahon ${ }^{12}$,

Simon Pooley ${ }^{13}$, Camilla Sandström ${ }^{14}$, Annelie Sjölander-Lindqvist ${ }^{15}$,

Ketil Skogen ${ }^{16}$, John E. Swenson ${ }^{3,17}$, Arie Trouwborst ${ }^{18}$, Juliette Young ${ }^{19}$

and EJ. Milner-Gulland ${ }^{20}$

${ }^{1}$ Institute of Biological \& Environmental Sciences, Zoology Building, Tillydrone Av.,

University of Aberdeen, Aberdeen, AB24 2TZ, UK

${ }^{2}$ Department of Ecology, Swedish University of Agricultural Science, Grimso Wildlife

Research Station, SE-730 91 Riddarhyttan, Sweden

${ }^{3}$ Norwegian Institute for Nature Research, PO Box 5685 Sluppen, NO-7485

Trondheim, Norway

${ }^{4}$ Département de biologie, Université de Sherbrooke, Sherbrooke, Québec J1K 2R1,

Canada

${ }^{5}$ Department of Biology and Biotechnologies, University of Rome “La Sapienza,"

Viale dell'Università 32, 00185 Roma, Italy

${ }^{6}$ Department of Biological and Environmental Sciences, Faculty of Natural Sciences,

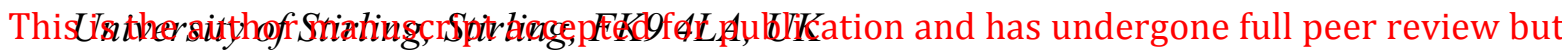
has not been through the copyediting, typesetting, pagination and proofreading process, which may lead to differences between this version and the Version of Record. Please cite this article as doi: $10.1111 /$ brv.12326

This article is protected by copyright. All rights reserved. 
${ }^{7}$ Wildlife Conservation Research Unit, Zoology Department, University of Oxford, The Recanati-Kaplan Centre, Tubney House, Abingdon Road,Tubney, Abingdon $O X 135 Q L, U K$

${ }^{8}$ Department of Fisheries and Wildlife, University of Minnesota, St. Paul, Minnesota 87102, USA

${ }^{9}$ James Hutton Institute, Craigiebuckler, Aberdeen AB34 4YN, UK

${ }^{10}$ Environmental Psychology, Dept of Architecture and Built Environment, Lund University, PO Box 118, 221 Lund, Sweden

${ }^{11}$ Biology Department, Biotechnical Faculty, Jamnikarjeva ulica 101, SI-1000

Ljubljana, Slovenia

${ }^{12}$ UCD School of Agriculture and Food Science, University College Dublin, Belfield, Dublin 4, Ireland

${ }^{13}$ Department of Geography, Environment and Development Studies, Birkbeck, University of London, 32 Tavistock Square, London WC1H 9EZ, UK

${ }^{14}$ Department of Political Science, Umeå University, SE-901 87 Umeå, Sweden

${ }^{15}$ Gothenburg Research Institute, University of Gothenburg, Box 603, 40530

Göteborg, Sweden

${ }^{16}$ Norwegian Institute for Nature Research, Gaustadalleen 21, 0349 Oslo, Norway

${ }^{17}$ Faculty of Environmental Sciences and Natural Resource Management, Norwegian University of Life Sciences, PO Box 5003, NO - 1432 As, Norway

${ }^{18}$ Department of European and International Public Law, Tilburg University, PO Box 90153, 5000 LE Tilburg, The Netherlands

${ }^{19}$ NERC Centre for Ecology and Hydrology, Bush Estate, Penicuik EH26 OQB, UK

${ }^{20}$ Tasso Leventis Professor of Biodiversity, University of Oxford, Department of Zoology and Merton College, South Parks Road, Oxford OX1 3PS, UK

This article is protected by copyright. All rights reserved. 
*Author for correspondence (E-mail: s.redpath@abdn.ac.uk; Tel.: 01224 274181).

\section{ABSTRACT}

Finding effective ways of conserving large carnivores is widely recognised as a priority in conservation. However, there is disagreement about the most effective way to do this, with some favouring top-down "command and control" approaches and others favouring collaboration. Arguments for coercive top-down approaches have been presented elsewhere; here we present arguments for collaboration. In many parts of the developed world, flexibility of approach is built into the legislation, so that conservation objectives are balanced with other legitimate goals. In the developing world, limited resources, poverty and weak governance mean that collaborative approaches are likely to play a particularly important part in carnivore conservation. In general, coercive policies may lead to the deterioration of political legitimacy and potentially to non-compliance issues such as illegal killing, whereas collaborative approaches may lead to psychological ownership, enhanced trust, learning, and better social outcomes. Sustainable hunting/trapping plays a crucial part in the conservation and management of many large carnivores. There are many different models for how to conserve carnivores effectively across the world, research is now required to reduce uncertainty and examine the effectiveness of these approaches in different contexts.

Key words: predator management, conservation, carnivores, conflict, collaboration, top-down, bottom-up, hunting.

\section{CONTENTS}


I. Introduction

II. Legislation for carnivore conservation

III. Democracy and legitimacy

IV. Collaborative governance

V. Hunting and carnivore populations

VI. Illegal killing

VII. The role of science

VIII. Discussion

IX. Conclusions

X. Acknowledgements

XI. References

\section{INTRODUCTION}

There is a fundamental disagreement about how best to conserve large predators in the Anthropocene. Some argue for coercive policies (Treves et al., 2017), whereas others argue for collaborative strategies (Lundmark, Matti, \& Sandström, 2014). Treves et al. (2017) have taken a particularly strong position for a protectionist approach, whilst pointing out that the state has an obligation to conserve large predators in trust for current and future citizens. They argued that this could be accomplished for wolves Canis lupus in the USA by “...sophisticated, careful accounting by disinterested trustees who can both understand the multidisciplinary scientific measurements of relative costs and benefits among competing uses.." (p. 1). They claimed that strong, top-down and protectionist control needs to be exerted over the "..tyrannies of the minorities, or majorities, who may demand depletion of unpopular, native wildlife.." (p. 18). They rejected the idea of sustainable population

This article is protected by copyright. All rights reserved. 
management, because they believed that the science guiding sustainable management is uncertain and disputed. They argued that without stronger control, hunting, trapping and poaching would lead to the eradication of predators.

Here we consider the potential merits of collaborative approaches, counterbalancing the arguments of Treves et al. (2017). While we wholeheartedly share their objective to conserve predators for current and future generations, we question the sole focus on a coercive approach for six reasons: (1) large predators mostly co-occur with people in multi-functional landscapes, where collaborative approaches are more appropriate; (2) a coercive approach raises moral issues and issues related to political legitimacy; (3) collaborative approaches are mandated by legislation in many countries and many international Directives; (4) in many parts of the world, the state does not have the capacity to impose and implement strongly enforced, top-down policies; (5) many predator populations thrive in the presence of hunting/trapping programs (hereafter just referred to as hunting) supported by local people; (6) a range of methods are already in use for the calculation and implementation of sustainable hunting limits. We conclude that both top-down and bottom-up governance approaches have validity in predator conservation. Our approach as scientists should be to develop new research to reduce the uncertainties and understand the effectiveness of alternative strategies in different contexts, rather than advocating one approach to the exclusion of all others. The arguments exemplified by Treves et al. (2017) and this response are critical for the future viability of predator populations, the ecosystems where they live, the legitimacy of management institutions and the well-being of people who live with them.

\section{LEGISLATION FOR CARNIVORE CONSERVATION}


Legislation can provide a supportive framework for changing the relationship between people and predators and for addressing the conservation conflicts associated with shared landscapes, both at local and intergovernmental levels (Trouwborst, 2015a, $b$ ). In international wildlife law, public trust and related concepts, such as intergenerational equity and sustainable development are distinct features of the legal landscape (Sand, 2014; Treves et al., 2017). The many national and international legal instruments applicable to large carnivores allow a mixture of approaches that can help balance conservation with other interests.

In the USA, state governments hold and manage wildlife as a public trust, but the federal government can manage wildlife in special cases such as under the Endangered Species Act (ESA) when species are threatened or endangered. The ultimate goal of the ESA is for a species to achieve recovery goals so that it can be delisted and management authority returned to the states. The ESA explicitly prohibits the consideration of economic or social issues in listing decisions for protected species. However, various mechanisms are used to reduce social conflict between rural residents and federal authorities, resulting in de facto consideration of economic and social factors in the process of endangered species management (Thomas \& Verner, 1992).

In the European Union, conservation and other interests are balanced principally by the Habitats Directive. The Directive's primary aim is to achieve 'Favourable Conservation Status' (FCS) for such species and this is non-negotiable. However, how member states achieve FCS is largely up to them, according to the subsidiarity principle (Trouwborst, Boitani \& Linnell, 2017). Member States need to "take account of economic, social and cultural requirements and regional and local characteristics" [Article 2(3)]. In some situations, governments must enact and 
enforce a strict protection regime, although exemptions are allowed under certain conditions (Annex IV); in other situations, governments have flexibility to determine how they ensure FCS (Annex V). In principle, the better a predator population is faring, the more scope arises under the Directive for flexible, collaborative approaches regarding its conservation and management. This notion of broad stakeholder participation in decisions affecting wildlife also features strongly in other areas of legislation, such as the 1998 Aarhus Convention on Access to Information, Public Participation in Decision-making and Access to Justice in Environmental

\section{Matters.}

In developing countries, predator management faces very different challenges.

Conservation often ranks low on the agenda because of the competing pressures of poverty and other social concerns. Governments of developing countries have often set aside extensive areas of land for wildlife, but limited resources and poor governance (especially corruption) mean they are unable to manage those areas effectively, let alone the significant wildlife populations outside protected areas (Lindsey et al., 2014, 2016; Smith et al., 2003). Local communities often experience high costs from these governmentally imposed wildlife areas, such as displacement, disempowerment, restricted resource use, killing of poachers and high levels of wildlife damage, and receive few or no benefits, so are not predisposed to engage positively with government wildlife agencies (Brockington \& Igoe, 2006; Dickman, 2010; Ferraro, 2002). In many areas this sense of local resentment has been amplified by foreign governments being seen to impose their values on local wildlife management (Nzou, 2015). In such a landscape, a coercive approach to conservation such as currently applied may be counter-productive (Duffy et al., 2015). Conversely, engaging local communities as key stakeholders in conservation has proved highly 
effective even in remote areas of developing countries (Dickman \& Hazzah, 2016; Hazzah et al., 2014). Similarly, local ownership of wildlife, such as through community conservancies, can avoid many of the problems associated with wildlife areas imposed and managed by governments (Fabricius et al., 2013; Measham \& Lumbasi, 2013). Collaborative approaches to carnivore conservation therefore have a crucial role to play in developing countries.

\section{DEMOCRACY AND LEGITIMACY}

Democracy relates to a system of government based on a "belief in freedom and equality between people, in which power is held either by elected representatives or directly by the people themselves" (Cambridge Dictionary online 2017). Therefore, it is beholden on democratic countries to manage public-trust assets, such as carnivores, in an appropriate manner consistent with this definition. Central to this is political legitimacy, which is "the belief of the rightfulness of the state, in its authority to issue commands, so that those commands are obeyed not simply out of fear of sanctions or self-interest, but because they are believed in some sense to have moral authority, because subjects believe they ought to obey" (Barker, 1990). This makes legitimacy a condition where citizens surrender authority to a branch of government based on a judgement that the relationship between them and the state is proper. Thus, the political legitimacy of natural resource management policy is partly dependent on it being socially acceptable at a local level (Peterson, 2003). This acceptability is particularly likely to be rejected when local communities perceive that large, dangerous predators are imposed on them and they have to bear the risks of living with such species only to benefit distant elites (Dickman, 2010; Dickman \& Hazzah, 2016; Knight, 2000). When acceptability is rejected, political legitimacy suffers 
(Pearce \& Littlejohn, 1997), and resistance in the form of non-compliance and outright sabotage (e.g. illegal hunting) may ensue (Krange \& Skogen, 2011; von Essen et al., 2014).

\section{COLLABORATIVE GOVERNANCE}

Ansell \& Gash (2008, p. 544) defined collaborative governance as an "arrangement where one or more public agencies directly engage non-state stakeholders in a collective decision-making process that is formal, consensus oriented and deliberative and that aims to make or implement public policy or manage public programs or assets." Such approaches to large carnivore management have been applied in various parts of the world. For example, Norway has regional large carnivore committees, with local politicians appointed by the Ministry of the Environment, Sweden has wildlife management delegations at a regional level with politicians and stakeholders, and Finland has national, regional and local wolf management organizations including public and private actors. There is a similar approach in the USA, such as the Wolf Stakeholder Working Group in California or the Wolf Advisory Group in Washington (Lundmark \& Matti, 2015; Sandström et al., 2009; Sjölander-Lindqvist, Johansson \& Sandström, 2015). The primary tasks of such groups are often to develop and adopt management plans, determine or give advice on regional population targets, mitigate direct conflicts between wildlife and livestock and in some cases decide on quotas for large carnivore hunting. Stakeholders are often also included in monitoring and information sharing (Decker, Riley \& Siemer, 2012). These approaches seek to strengthen democracy by dealing with the problems related to a lack of both legitimacy and acceptance of centralized governance of large carnivore management (Sandström et al., 2009; Sjölander-Lindqvist et al., 2015; Torfing et al., 2012). They 
also offer an arena for conflict management.

There have been few evaluations of collaborative governance in conservation, making it difficult to draw general conclusions regarding its legitimacy or outcomes. We are certainly far from being able to design the ideal collaborative process, and in fact, recent studies have highlighted some deficiencies. There are problems related to the representation of different interests (Lundmark \& Matti, 2015), the lack of opportunities for deliberation (Hallgren \& Westberg, 2015), the lack of mechanisms for conflict resolution (Duit \& Lof, 2015) and misunderstandings of the mechanism by which decisions are made (Sandström et al., 2009). Nevertheless, in spite of these problems these studies also show the potential of collaborative processes to contribute to social and organizational learning, as well as contributing to the improvement of rules and regulations of wildlife management. Indeed, research suggests that those engaged in collaborative processes develop what has been termed the "psychological ownership' of the process, which can lead to enhanced trust between participants and an increased sense of responsibility for the governance and management of wildlife among the affected parties (Pierce, Kostova \& Dirks, 2001; Pohja-Mykrä \& Kurki, 2014a; Ratamäki, 2015).

Given the potential that collaborative processes have, there is an urgent need to understand what works in different contexts. We suggest that future studies should focus on four aspects: first, comparing collaborative governance approaches among countries, rather than focusing on individual case studies; second, understanding how institutional design and leadership interact with non-state actors' ideas and conceptualizations of collaborative governance; third, understanding how the social and cultural contexts of these actors inform the different governance models and their legitimate outcomes; and fourth, understanding the impact of the collaborative 
process on the conflict both within and outside the collaborative bodies (SjölanderLindqvist et al., 2015).

\section{HUNTING AND CARNIVORE POPULATIONS}

Rural stakeholders that share the landscape with carnivores often wish to hunt them.

Such practices do not necessarily lead to carnivore population declines. Indeed, populations can increase in the presence of hunting. For example, the Swedish brown bear (Ursus arctos) population has been increasing since the 1930s, from around 300 to over 3,000 by 2008, despite the resumption of hunting in 1943 (Kindberg et al., 2011; Swenson et al., 1995). Similarly, hunting areas such as Bubye Valley Conservancy in Zimbabwe, Niassa National Reserve and Namibia's communal conservancies are amongst the few places to record recent lion population increases (Bauer et al., 2016). Cougars (Puma concolor), have also been increasing in much of North America (Larue et al., 2012; Sweanor, Logan \& Hornocker, 2000) without being protected by the ESA and despite being hunted in nearly all of their range. Clearly, the ESA and the Habitats Directive are partly responsible for fostering recent increases in large carnivore populations (Fleurke \& Trouwborst, 2014). However, it is hard to disentangle the effects of legislation from the concurrent changes in land use, rebounding prey populations and more positive public attitudes towards carnivores. Indeed, it is likely that these influences act synergistically (Boitani \& Linnell, 2015). Although targets for sustainable harvesting of carnivores may be difficult to estimate accurately in some cases, partly because of the uncertainties involved, methods for sustainable harvesting under uncertainty are well established, with an extensive literature (dating back at least to Walters \& Hilborn, 1976). These techniques are applicable to carnivore management (e.g. Edwards et al., 2014). Large carnivores in 
Europe and North America are among the most intensively monitored and studied large mammals in the world (Chapron et al., 2014; Ripple et al., 2014; Clark \& Rutherford, 2014). This provides an adequate basis for harvesting, so long as caution is exercised and coupled with an adaptive adjustment of quotas. The challenge lies more with poor monitoring and enforcement of harvesting, as well as political priorities going against conservation, than with the underlying science.

\section{ILLEGAL KILLING}

One problem for the conservation of large predators is illegal killing. Central to this problem is the relationship between approaches to conservation and the likelihood of illegal activity taking place. Recently, Chapron \& Treves (2016) claimed that legal hunting of wolves led to an increase in illegal killings. Other studies, however, suggest the relationship is more complex. In Sweden, for example, the illegal killing of large carnivores was significantly higher within national parks, where they are strictly protected, than outside, where they are hunted (Rauset et al., 2016). In other studies, predator abundance seems to be important. Eriksson, Sandström \& Ericsson (2015) showed that an increase in direct experience of bears and wolves reduced both the levels of acceptance of these animals and support for wolf conservation over time, suggesting that local attitudes towards large carnivores are likely to deteriorate as populations increase (Williams et al., 2011; Dressel, Sandström \& Ericsson, 2015). In Croatia, attitudes towards brown bears became less positive coincident with a shift from local management that included hunting to more top-down protectionist policy (Maji et al., 2011). Pohja-Mykrä \& Kurki (2014b) take this a step further and suggest that illegal killing of wolves is a direct response to the failure of policy to take rural people's concerns seriously (see also Mech, 1995). In Kenya, Maasai 
respondents were more negative to lions Panthera leo, and more inclined to kill them, if they were denied access into protected areas to graze their livestock during droughts (Hazzah et al., 2013). Such a response may be compounded by the tendency of groups to enhance their internal cohesion under stress by blaming outside actors, such as management agencies (Skogen \& Krange, 2003).

It is unlikely that there would be one consistent response to a certain management intervention, such as legal hunting, that could be transferable among individuals, cultures and local contexts. Instead, an individual's behaviour towards carnivores will be a result of the complex interaction between underlying values, previous experience, norms, attitudes and trust in management authorities, set within a broader social and institutional context (Sjölander-Lindqvist et al., 2015). Consequently, we must understand the interplay between individuals' appraisal of the threat from carnivores, their attitudes and the community-wide social construction of danger before we can draw general conclusions about illegal killing.

\section{THE ROLE OF SCIENCE}

Science is fundamental in helping societies navigate through the controversies that surround carnivore conflicts. We need robust science to help inform decisions. Efforts have typically focused on a linear model of natural science providing evidence to guide policy and management strategies (Burgess, Harrison \& Filius, 1998; Sarewitz, 2004). Yet this approach has proved problematic for two main reasons. First, stakeholders may frame conflicts on the basis of emotion, values and worldviews, rather than evidence (Slovic, 1987). As a result science can be ignored or dismissed (Weber \& Stern, 2011). Second, science is often represented as objective truth, yet researchers may use science to legitimize normative positions (Lackey, 2004), leading 
to scientists not being trusted and the credibility of the science being questioned (Yamamoto, 2012). Thus, it is beholden on scientists to avoid claiming that normative positions are science-based but instead to engage fully with relevant stakeholders and the decision-making process, while developing robust evidence, and being transparent about the uncertainties as well as their role and the values they hold.

\section{DISCUSSION}

Finding ways to encourage coexistence between people and large predators in multifunctional landscapes is a major challenge for conservation worldwide (Carter \& Linnell, 2016; Di Minin et al., 2016). How can we encourage those with farming or other legitimate interests to share these landscapes with large predators that affect their livelihoods and lives?

There are different models for how to achieve coexistence. On the one hand, topdown, command-and-control approaches play a crucial role in carnivore conservation. Much of the increase in large carnivore populations across parts of Europe and the USA can be attributed to legislation and its enforcement. Where carnivore populations are very low, strict protection may be appropriate and more acceptable to people living with carnivores, as their impacts on daily life are likely to be minimal and attitudes are more positive. However, as carnivore populations recover and have increasing impacts on more people, we suggest that a different approach is required.

In such situations, imposing coercive approaches that may not resonate locally risks alienating local stakeholders, leading to, for example, increased carnivore killing and greater conflict (Brockington \& Igoe, 2006). Instead, we suggest that more collaborative and flexible approaches are required to build trust and negotiate the challenges of living equitably and sustainably with carnivores. This approach is 
inherently more democratic, as well as being embedded in current legislation and in international conventions, such as the Convention on Biological Diversity (Glowka, Burhenne-Guilmin, \& Synge, 1994).

Evidence for the relative effectiveness of alternative approaches is not always available (Reed \& Sidoli del Ceno, 2015). There are many uncertainties in developing effective strategies for predator conservation in multi-use landscapes. We are not advocating one approach over another, we rather highlight that we must better understand what works when and where. Different models are likely to be context dependent, and we must recognize that different stakeholder groups and publics have different views and desires at different scales.

The need for robust science is clear, not only to explore the effectiveness of alternative management approaches in different contexts, but also to support the sustainable management of hunting and to understand the factors that affect illegal behaviour. Treves et al. (2017) call for an independent, national-level, external body, informed by science, to adjudicate issues around carnivore management. Such approaches may provide useful input for top-down predator management, but they are doomed to fail unless they are balanced by more bottom-up, collaborative processes. There is increasing evidence that simply providing the results of natural science to managers is not enough. A more effective route is likely to be through developing a more integrative, trans-disciplinary approach to knowledge with the appropriate stakeholders (Bennett et al., 2017).

\section{CONCLUSIONS}

(1) There is disagreement about the most effective way to conserve large carnivores, with some favouring top-down 'command and control' approaches and others 
favouring more collaborative approaches. Herein we examine arguments for collaboration.

(2) Flexibility is built into the legislation in the USA and Europe to balance conservation with other legitimate goals. In the developing world, collaborative approaches are likely to play a particularly important part in carnivore conservation.

(3) Coercive policies may lead to the deterioration of political legitimacy and potentially to non-compliance, including illegal carnivore killing.

(4) Collaborative approaches may lead to enhanced trust, learning and better social outcomes.

(5) Hunting can be part of the sustainable management of large carnivores.

(6) Research is required to reduce uncertainty and examine the effectiveness of alternative approaches to carnivore conservation in different contexts.

\section{ACKNOWLEDGEMENTS}

S.R. is grateful for the King Carl XVI Gustav guest professorship that allowed him to write this paper. J.D.C.L. was supported by the Research Council of Norway (grant number 251112). A.S.-L. was supported by the Swedish Research Council (grant number 421-2014-1446). A.T. was supported by the Netherlands Organisation for Scientific Research (grant number 452-13-014). We thank L. David Mech and two anonymous referees for helpful suggestions.

\section{REFERENCES}

ANSELl, C. \& GASH, A. (2008). Collaborative governance in theory and practice. Journal of Public Administration Research and Theory 18, 543-571. 
BARKer, R. (1990). Political Legitimacy. In Political Legitimacy and the State (pp. 20-42).

Bauer, H., Packer, C. Funston, P. F. Henschel, P. \& K. Nowell. (2016). Panthera leo. The IUCN Red List of Threatened Species 2016.

\section{http://www.iucnredlist.org/details/15951/0}

Bennett, N. J., Roth, R., Klain, S. C., Chan, K. M. A., Clark, D. A., Cullman, G., Epstein, G., Nelson, M.P., Stedman, R., Teel, T.L. Thomas, R.E.W. Wyborn, C., Curran, D., Greenberg, A., SAndlos, J. \& Veríssimo, D. (2017). Mainstreaming the social sciences in conservation. Conservation Biology 31, 56-66.

BoITANI, L. \& LinNELL, J. D. C. (2015). Bringing large mammals back: large carnivores in Europe. In Rewilding European Landscapes (pp. 67-84). Springer International Publishing.

BROCKINGTON, D. \& IGOE, J. (2006). Eviction for conservation: a global overview. Conservation and Society 4(3), 424-470.

BURGESS, J., HARRISON, C. M. \& FILIUS, P. (1998). Environmental communication and the cultural politics of environmental citizenship. Environment and Planning $A$ 30, 1445-1460.

CARTer, N. H. \& LinNell, J. D. C. (2016). Co-adaptation is key to coexisting with large carnivores. Trends in Ecology \& Evolution 31(8), 575-578.

Chapron, G., Kaczensky, P., Linnell, J.D., Von ArX, M., Huber, D., Andrén, H., LÓPez-BAo, J.V., AdAmec, M., Álvares, F., ANDERs, O., BAl iAuskas, L., BALYs, V., BEDO, P., BEGO, F., BlANCO, J.C. ET AL. (2014). Recovery of large carnivores in Europe's modern human-dominated landscapes. Science 346(6216), pp.1517-1519.

This article is protected by copyright. All rights reserved. 
Chapron, G. \& Treves, A. (2016). Blood does not buy goodwill: allowing culling increases poaching of a large carnivore. Proceedings of the Royal Society B $\mathbf{2 8 3}$ (1830), 20152939.

ClARK, S. G. \& RUTHERFORD, M. B. (Eds.). (2014). Large carnivore conservation: integrating science and policy in the North American West. University of Chicago Press.

DeCKER, D.J., Riley, S.J. \& SiEMER, W. F. (Eds.). (2012). Human dimensions of wildlife management. JHU Press.

DiCKMAN, A. (2010). Complexities of conflict: the importance of considering social factors for effectively resolving human-wildlife conflict. Animal Conservation 13, $458-466$.

DiCKMAN, A. J. \& HAZZAH, L. (2016). Money, myths and man-eaters: complexities of human-wildlife conflict. In F. Angelici, (Ed). Problematic Wildlife. pp. 339-356. Springer, Rome, Italy.

Di Minin, E., Slotow, R., Hunter, L. T. B., Montesino Pouzols, F., Toivonen, T., Verburg, P. H., Leader-Williams, N., Petracca, L. \& Moilanen, A. (2016).

Global priorities for national carnivore conservation under land use change. Scientific Reports 6, 23814.

Dressel, S., SANDSTRÖM, C. \& ERICSSON, G. (2015). A meta-analysis of studies on attitudes toward bears and wolves across Europe 1976-2012. Conservation Biology 29(2), 565-574.

Duffy, R., St John, F. A., Büscher, B. \& Brockington, D. (2015). The militarization of anti-poaching: undermining long term goals? Environmental Conservation 42(04), 345-348. 
Duit, A., \& LöF, A. (2015). Dealing with a wicked problem? A dark tale of carnivore management in Sweden 2007-2011. Administration \& Society 1-25.

Edwards, C. T. T., Bunnefeld, N., Balme, G. A. \& Milner-Gulland, E. J. (2014). Data-poor management of African lion hunting using a relative index of abundance. Proceedings of the National Academy of Sciences of the United States of America 111(1), 539-543.

ERIKSSON, M., SANDSTRÖM, C. \& ERICSSON, G. (2015). Direct experience and attitude change towards bears and wolves. Wildlife Biology 21(3), 131-137.

FABricius, C., Koch, E., TuRner, S. \& MAgOme, H. (Eds.). (2013). Rights resources and rural development: Community-based natural resource management in Southern Africa. Routledge.

FERRARO, P. J. (2002). The local costs of establishing protected areas in low-income nations: Ranomafana National Park, Madagascar. Ecological Economics 43(2), 261275.

FLEURKE, F.M., \& TROUWBorst, A. (2014). European regional approaches to the transboundary conservation of biodiversity: the Bern Convention and the EU Birds and Habitats Directive. In L. Kotze \& T. Marauhn (Eds.), Transboundary Governance of Biodiversity. (pp. 128-162).

GlowkA, L., BurhenNe-Guilmin, F. \& Synge, H. (1994). A guide to the convention on biological diversity. Environmental Policy and Law Paper. Retrieved from http://books.google.com.br/books?hl=pt-

$\underline{\text { BR\&lr }=\& \mathrm{id}=\mathrm{xInED} \_\mathrm{dq} 2 \text { yoC\&oi }=\text { fnd } \& p g=\mathrm{PP} 14 \& \mathrm{dq}=\text { convention }+ \text { on }+ \text { biological }+ \text { div }}$

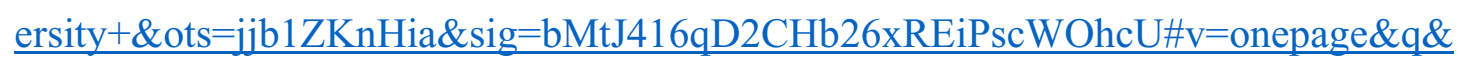
$\underline{f=\text { false }}$

This article is protected by copyright. All rights reserved. 
Hallgren, L. \& Westberg, L. (2015). Adaptive management? Observations of knowledge coordination in the communication practice of Swedish game management. Wildlife Biology 21(3), 165-174.

HazZAh, L., Dolrenry, S., KAPlan, D. \& Frank, L. (2013). Access to parks during drought influences attitudes and behavior toward lion conservation in Maasailand, Kenya. Environmental Conservation 40, 266-276.

Hazzah, L., Dolrenry, S., Naughton, L., Edwards, C. T. Mwebi, O. Kearney, F. \& FRANK, L. (2014). Efficacy of two lion conservation programs in Maasailand, Kenya. Conservation Biology 28, 851-860.

Kindberg, J., Swenson, J. E., Ericsson, G., Bellemain, E., Miquel, C. \& TABERLET, P. (2011). Estimating population size and trends of the Swedish brown bear Ursus arctos population. Wildlife Biology 17(2), 114-123.

KNIGHT, J. (2000). Natural enemies: people-wildlife conflicts in anthropological perspective. Psychology Press.

Krange, O. \& Skogen, K. (2011). When the lads go hunting: The 'Hammertown mechanism' and the conflict over wolves in Norway. Ethnography 12(4), 466-489.

LACKEY, R. (2004). Normative Science. Fisheries 29(7), 38-39.

Larue, M. A., Nielsen, C. K., Dowling, M., Miller, K., Wilson, B., Shaw, H. \& ANDERSON, C. R. (2012). Cougars are recolonizing the midwest: analysis of cougar confirmations during 1990-2008. Journal of Wildlife Management 76(7), 1364-1369.

Lindsey, P. A., Balme, G. A., Funston, P. J., Henschel, P. \& Hunter, L. T. (2016). Life after Cecil: channeling global outrage into funding for conservation in Africa. Conservation Letters 9(4), 296-301.

Lindsey, P.A., NyiRENDA, V.R., BARnes, J.I., BECKER, M.S., McRobB, R., TAmbling, C.J., TAYlor, W.A., WATson, F.G. \& T'SAs-Rolfes, M. (2014).

This article is protected by copyright. All rights reserved. 
Underperformance of African protected area networks and the case for new conservation models: insights from Zambia. PLoS one 9(5), e94109.

LUNDMARK, C. \& MATTI, S. (2015). Exploring the prospects for deliberative practices as a conflict-reducing and legitimacy-enhancing tool: the case of Swedish carnivore management. Wildlife Biology 21(3), 147-156.

LUNDMARK, C., MATTI, S. \& SANDSTRÖM, A. (2014). Adaptive co-management: how social networks, deliberation and learning affect legitimacy in carnivore management. European Journal of Wildlife Research 60(4), 637-644

Maji ,A., Marino Taussig de Bodonia, A., Huber, D. \& Bunnefeld, N. (2011). Dynamics of public attitudes toward bears and the role of bear hunting in Croatia. Biological Conservation 144, 3018-3027.

MeAsham, T. G. \& LUMBASI, J. A. (2013). Success factors for community-based natural resource management (CBNRM): lessons from Kenya and Australia. Environmental Management 52(3), 649-659.

MECH, L. D. (1995). The challenge and opportunity of recovering wolf populations. Conservation Biology 9(2), 270-278.

NzoU, G. (2015). In Zimbabwe, we don't cry for lions. The New York Times, $4^{\text {th }}$ August 2015. Available from http://www.nytimes.com/2015/08/05/opinion/inzimbabwe-we-dont-cry-for-lions.html?_r=0 (accessed 11 October 2016). PeARCE, W. B. \& LitTlejohn, S. W. (1997). Moral conflict: when social worlds collide. Thousand Oaks, CA: Sage.

PETERSON, T. R. (2003). Social control frames: Opportunities or constraints? Environmental Practice 5(3), 232-238.

Pierce, J. L., Kostova, T. \& Dirks, K. T. (2001). Toward a theory of psychological ownership in organizations. Academy of Management Review 26(2), 298-310. 
POHJA-MYKRÄ, M. \& KURKI, S. (2014a). Evaluation of the Finnish national policy on large carnivores. University of Helsinki. Reports 135.

POHJA-MYKRÄ, M., \& KURKI, S. (2014b). Strong community support for illegal killing challenges wolf management. European Journal of Wildlife Research 60(5), $759-770$.

RATAMÄKI, O. (2015). Elements, orders, and modes of governance in the development of Finnish wolf policy. In M. M. Merviö (Ed.), Management and Participation in the Public Sphere. (pp. 38-61).

Rauset, G. R., Andrén, H., Swenson, J. E., SAmelius, G., Segerström, P., Zedrosser, A. \& Persson, J. (2016). National Parks in Northern Sweden as refuges for illegal killing of large carnivores. Conservation Letters 9, 334-341.

REED, M.S \& SidOLI DEL CENO, J. (2015). Mediation and conservation conflicts: from top-down to bottom up. In: Redpath, S.M., Gutierrez, R.J., Wood, K.A. \& Young J.C. (Eds). Conflicts in Conservation - Navigating towards solutions. (pp. 226-237).

Cambridge University Press.

Ripple, W.J., Estes, J.A., Beschta, R.L., Wilmers, C.C., Ritchie, E.G., HebBlewhite, M., Berger, J., Elmhagen, B., Letnic, M., Nelson, M.P., Schmitz, O.J., SMith, D.W.,WALlach, A.D. \& Wirsing, A.J. (2014). Status and ecological effects of the world's largest carnivores. Science 343, 1241481, 1-13.

SAND, P. H. (2014). The rise of public trusteeship in international environmental law. Environmental Policy and Law 44(1), 210-218.

SANDStröm, C., PellikKa, J., RAtamäKi, O. \& SANDE, A. (2009). Management of large carnivores in Fennoscandia: new patterns of regional participation. Human Dimensions of Wildlife 14, 37-50. 
SAREWITZ, D. (2004). How science makes environmental controversies worse.

Environmental Science and Policy 7, 385-403.

SJÖLANDER-LindQVist, A., JoHANSSON, M. \& SANDSTRÖM, C. (2015). Individual and collective responses to large carnivore management: the roles of trust, representation, knowledge spheres, communication and leadership. Wildlife Biology 21(3), 175-185.

SKoGEN, K. \& KRANGe, O. (2003). A wolf at the gate: the anti-carnivore alliance and the symbolic construction of community. Sociologia Ruralis 43(3), 309-325.

SLOVIC, P. (1987). The perception of risk. Science 236, 280-285.

Smith, R. J., Muir, R. D., Walpole, M. J., Balmford, A. \& Leader-Williams, N. (2003). Governance and the loss of biodiversity. Nature 426(6962), 67-70.

SweAnOR, L. L., Logan, K. A. \& Hornocker, M. G. (2000). Cougar dispersal patterns, metapopulations dynamics, and conservation. Conservation Biology 14(3), 798-808.

Swenson, J. E., Wabakken, P., SAndegren, F., BJÄrvall, A, Franzén, R. \& SÖRDERBERG, A. (1995). The near extinction and recovery of brown bears in Scandinavia in relation to the bear management policies of Norway and Sweden. Wildlife Biology 1, 11-25.

Thomas, J. W. \& Verner, J. (1992). Accommodation with socioeconomic factors under the endangered species act-more than meets the eye. Transactions of the North American Wildlife and Natural Resources Conference 57, 627-641.

Torfing, J., Peters, B. G., Pierre, J. \& Eva S. (2012). Power and politics in interactive governance. In: Interactive Governance: Advancing the Paradigm (pp. 48$71)$.

This article is protected by copyright. All rights reserved. 
Treves, A., Chapron, G., López-Bao, J. V., Shoemaker, C., Goeckner, A. R. \& BRUsKotter, J. T. (2017). Predators and the public trust. Biological Reviews 92, 248270.

TrOUWBORST, A. (2015a). Global large carnivore conservation and international law. Biodiversity and Conservation, 24(7), 1567-1588.

TrouwBorst, A. (2015b). Law and conservation conflicts. In: Redpath, S.M., Gutiérrez, R.J., Wood, K.A. \& Young, J.C. (Eds) Conflicts in conservation: navigating towards solutions. pp. 108-118. Cambridge University Press, Cambridge. Trouwborst, A., Boitani, L. \& Linnell, J.D.C. (2017). Interpreting 'favourable conservation status' for large carnivores in Europe: how many are needed and how many are wanted? Biodiversity and Conservation 26(1), 37-61.

von Essen, E., Hansen, H. P., Nordström, Källström, H., Peterson, M. N. \& PETERSON, T. R. (2014). Deconstructing the poaching phenomenon: a review of typologies for understanding illegal hunting. British Journal of Criminology 54(4), $632-651$.

Walters, C. J. \& Hilborn, R. (1976). Adaptive control of fishing systems. Journal of the Fisheries Research Board of Canada 33(1), 145-159.

Weber, E. U. \& Stern, P. C. (2011). Public understanding of climate change in the United States. American Psychologist 66(4), 315-328.

Williams, P.S., Darville, R., Keul, A., LegG, M., Garner, N. \& Comer, C. (2011). Stakeholders' attitudes towards black bear in East Texas. Human Dimensions of Wildlife 16(6), 414-424.

YAмамото, Y. T. (2012). Values, objectivity and credibility of scientists in a contentious natural resource debate. Public Understanding of Science 21, 101-125. 


\section{University Library}

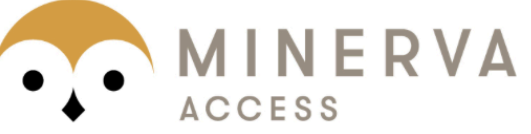

A gateway to Melbourne's research publications

Minerva Access is the Institutional Repository of The University of Melbourne

\section{Author/s:}

Redpath, SM;Linnell, JDC;Festa-Bianchet, M;Boitani, L;Bunnefeld, N;Dickman, A;Gutierrez, RJ;Irvine, RJ;Johansson, M;Majic, A;McMahon, BJ;Pooley, S;Sandstrom, C;SjolanderLindqvist, A;Skogen, K;Swenson, JE;Trouwborst, A;Young, J;Milner-Gulland, EJ

Title:

Don't forget to look down - collaborative approaches to predator conservation

Date:

2017-11-01

Citation:

Redpath, S. M., Linnell, J. D. C., Festa-Bianchet, M., Boitani, L., Bunnefeld, N., Dickman, A., Gutierrez, R. J., Irvine, R. J., Johansson, M., Majic, A., McMahon, B. J., Pooley, S., Sandstrom, C., Sjolander-Lindqvist, A., Skogen, K., Swenson, J. E., Trouwborst, A., Young, J. \& Milner-Gulland, E. J. (2017). Don't forget to look down - collaborative approaches to predator conservation. BIOLOGICAL REVIEWS, 92 (4), pp.2157-2163. https://doi.org/10.1111/brv.12326.

Persistent Link:

http://hdl.handle.net/11343/292705 